\title{
Hand hygiene attitudes of healthcare staff working in intensive care unit of a state hospital
}

\section{Bir devlet hastanesinin yoğun bakım ünitesinde çalıșan sağlık personelinde el hijyeni davranișları}

\author{
Aliye BULUT ${ }^{1}$, Aziz BULUT², Çağla YiĞiTBAŞ ${ }^{3}$, Suat TUNCAY'
}

\section{ABSTRACT}

Objective: The purpose in this research is to evaluate hand hygiene the attitudes of healthcare staff working in intensive care unit of state hospital of a province in Eastern Anatolia Region.

Methods: The research was conducted by applying to a survey to healthcare personnel delivering patient care and treatment services in coronary, anesthesia and internal medicine intensive care clinics of a state hospital located in Eastern Anatolia Region. The universe of the research is comprised of 51 healthcare staff working in this hospital and was conducted on the basis of voluntary participation with whole of the universe of the research (51 people) (Response rate: 100\%). Survey form used in the research was developed by researchers in compliance with literature information. Data were evaluated in statistic packaged software.

Results: The average age of the people attending the study is $31,66 \pm 7,34$ (min: 18 , max: 56 ) and $53 \%$ of them is woman and $54,9 \%$ is nurse. The most prefered method of hand washing is (at the rate of $68,6 \%$ ) water and soap and also it was found that $84,3 \%$ of the frequency of hand washing is expressed as often. On the other hand, it was detected that $23,5 \%$ of the participants could not was their hands because of deficiency of material, $11,8 \%$
ÖZET

Amaç: Bu araștırmada amaç, Doğu Anadolu Bölgesindeki bir ilimizin Devlet Hastanesinin Yoğun Bakım Ünitesinde çalışan sağlık personelinin el hijyeni ile ilgili davranışlarının değerlendirilmesidir.

Yöntem: Araștırma, Doğu Anadolu Bölgesinde yer alan bir Devlet Hastanesinin Koroner, Anestezi ve Dâhiliye Yoğun Bakım Kliniklerinde hasta bakım ve tedavi hizmeti veren sağlık çalışanlarına anket uygulanması yoluyla gerçekleștirilmiștir. Araștırmanın evrenini bu hastanede çalıșan 51 sağlık personeli olușturmuș, araștırma evreninin tamamı ile (51 kişi) gönüllü katılım esasına göre yürütülmüștür (Cevaplılık oranı: \%100). Araștırmada kullanılan anket formu literatür bilgisine uygun olarak araștırmacılar tarafından geliștirilmiștir. Veriler istatistik paket programında değerlendirilmiștir.

Bulgular: Çalıșmaya katılan kișilerin yaș ortalamaları 31,66 \pm 7,34 (min: 18, max: 56) șeklinde olup \%53,0'ü kadınlardan ve \%54,9'u hemșirelerden olușmaktadır. El yıkamada en çok tercih ettikleri yöntemin (\%68,6 oranında) su ve sabun olduğu ayrıca el yıkama sıklıklarının \%84,3 oranında sık sık șeklinde ifade edildiği saptanmıștır. Katılımcıların, \%23,5'inin malzeme yetersizliği, \%11,8'inin yoğun

* This study was submitted as poster declaration in 18th National Public Health Congress between 05-09th of October, 2015.

'Bingöl University, Faculty of Health Sciences

${ }^{2}$ Bingöl State Hospital

${ }^{3}$ Giresun University, Faculty of Health Sciences

İletişim / Corresponding Author : Aliye BULUT

DOI ID : 10.5505/TurkHijyen.2017.43815

Bulut A, Bulut A, Yigitbas C, Tuncay S. Hand hygiene attitudes of healthcare staff working in intensive care unit of a state hospital.

Turk Hij Den Biyol Derg, 2017; 74(2): 139-146 
because of lack of time arising from intense work load, $7,8 \%$ because of occurrence of irritation in their hands.

Conclusion: Hand washing behavior of staff working at public hospital in intensive care is not at desirable level, and also the physical conditions are not sufficient for this case. For this reason, it is significant that staff in state hospital rendering service in primary areas such as intensive care unit should be subjected to on-the-job trainings with repetitive applications to maintain the health of both themselves and the individuals they render care service at an optimum level and to gain attitude of hand washing with scientific methods and in this sense, it is important to provide technical and adequate equipment to the hospital.

Key Words: Hand washing, intensive care, healthcare staff

\section{INTRODUCTION}

Progressively gaining importance in the twenty first century, hospital infection is among the most significant problems that modern medicine has to deal with (1). Hand washing is the most substantial precaution that healthcare staff can take regarding the hospital infections that may arise in patients and the risks they are exposed to in workplace environment and once again is a simple procedure that is thought to be critical in control of infections acquired in healthcare staff by occupational means ( 2 , 3 ). Hand hygiene is the most efficient and substantive factor in prevention of hospital infection (4).

The purpose of hand washing specified by unions such as Center for Disease Control and Prevention (CDC), American Hospital Association (AHA) and Association for Professionals in Infection Control and Epidemiology (APIC) as an application having vital importance in breaking infection chain by iș yükü nedeniyle zaman yetersizliği, \%7,8'inin ise, ellerinin tahriş olmasından dolayı el yıkayamadığı belirlenmiștir.

Sonuç: Araștırmanın yapıldığı Devlet Hastanesi Yoğun Bakımında çalıșan sağlık personelinin el yıkama davranışının istendik düzeyde ve șekilde olmadığı öte yandan fiziki koșulların da bu durum için yeterli olmadığı saptanmıștır. Bu nedenle Devlet Hastanesinde yoğun bakım ünitesi gibi öncelikli alanlarda hizmet verenlerin hem kendileri hem de bakım sundukları bireylerin sağlığını optimum düzeyde sürdürebilmeleri ve bilimsel metotlarla el yıkama davranıșı edinmeleri için tekrarlı uygulamalarla hizmet içi eğitimlere tabi tutulmaları, bu manada hastanenin teknik ve yeterli donanımsal araçlara kavușturulması önemlidir.

Anahtar Kelimeler: El Yıkama, yoğun bakım, sağlık çalıșanları

fecal oral and inhalation means is to clean transient microorganisms, oil and dirt on hand and thus to prevent microorganism transmission to the patients prone to infection by preventing regeneration of microorganisms for a certain period of time $(5,6)$.

It is known that hospital infections, being one of the significant problems threatening the people staying in the hospital and healthcare staff, cause redundant bed occupation, workforce loss and increase in treatment costs and accordingly place an extra burden to national economy (7-10). The frequency of incidence of hospital infections is known to be affected by the size of the hospital, architectural structure, the number and knowledge level of personnel, the status of the patients accepted, diagnosis applied and treatment methods and control and measures of protection concerning infections $(11,12)$. It has been emphasized that 
change and development in the applications in healthcare in recent years has increased the quality of life and patient safety and extended length of life; notwithstanding, led to generation of new pathogens; changes in resistance and increase in hospital infections (13).

World Health Organization (WHO) reports that more than 190 million of people are hospitalized in the world each year and it is known that hospital infection occurs in $5 \%$ of these, that is to say that 10 million, and therefore patients stay in hospitals more than 7 days in average (14-18). It has been expressed in the studies carried out that urinary system (36\%), surgical site $(22 \%)$, lower respiratory tract infections (9\%) and bacteremia (12\%) are mostly efficient in hospital infections rates, which is between $3.1 \%$ and $14.1 \%$ in the world and $2 \%$ and $16.5 \%$ in our country (19-22). It has been determined in a study covering 56 intensive care units of twenty two university hospitals that hospital infection was developed in 115 of 236 patients (48\%) (23).

Intensive care units provide substantial opportunities in close surveillance of the patients, not stabile in physiological terms. In addition to this, these units establish an environment rich in resistant pathogen bacteria due to the fact that they are areas where broad-spectrum antibiotics are commonly used. Mechanical ventilation, central vein and artery catheterization, total parenteral nutrition, urinary catheter, dialysis, blood products, surgical and medical interventions are required in intensive care patients mostly. Usually, this kind of invasive monetarization and treatment rescues life, while on the other hand causes risks that may create hospital infections. Frequently, immune system of intensive care patient is suppressed because of shock, bleeding, surgical operation, malnutrition or other underlying diseases. For this reason, the greater part of hospital an infection is observed in intensive care patients (24-26).

The aim of this study was to investigate the practices and knowledge level about hand hygiene among health care working in our hospital of intensive care workers.

\section{MATERIAL and METHOD}

The universe of descriptive research is comprised of healthcare staff working in Coronary, Anesthesia and Internal Diseases Intensive Care Clinics of a province in service at Bingöl State Hospital. The study was conducted by way of applying a questionnaire to healthcare staff rendering patient care and treatment service in intensive care units after the permission of the institution and approval of ethical committee are obtained. The data are collected between 18th of June - 18th of July, 2015 and 51 healthcare personnel in total serving in intensive care unit ( 9 physicians, 28 nurses, 5 medical assistants, 9 auxiliary staff) are included in the study. Any sample choice has not applied in the research and carried out on voluntary basis with whole of the universe of the research (51 people) (response rate: \%100). 2 physicians, 8 nurses, 2 medical assistants and 2 auxiliary staff work in internal diseases intensive care; 3 physicians, 11 nurses, 3 medical assistants, 5 auxiliary staff works in anesthesia intensive care; 4 physicians, 9 nurses and 2 auxiliary staff in coronary intensive care.

Survey form used in the research was developed by researchers in association with the literature information. Survey form comprises of the questions questioning socio-demographic features (6 questions), occupational features and status of adoption of the occupation ( 9 questions) and also knowledge, attitudes and applications of the issue of hand washing (16 questions). Surveys face-to-face interview technique was applied.

Independent variables of the research are variables surveying socio-demographic features and dependent variables are knowledge, attitude and practices on the issue of hand washing. Data were evaluated in statistics package software. The frequencies for defining variables were shown together 
with percentages. Averages are shown together with standard deviation and designated as $p<0.05$ significance level. The study 's results are displayed with frequency and percentage distributions.

\section{RESULTS}

51 healthcare staff working in Coronary, Anesthesia and Internal Diseases Intensive Care Clinics attended to the study. The average age of the people participated in the research was determined as 31.66 \pm 7.34 (min:18, max: 56). 53,0\% (27 personnel) of the healthcare staff attended to the study was woman and 54,9\% (28 personnel) was nurse.
$45,1 \%$ (23) of the staff participated in the study was graduated from associate degree and 19,6\% (10) from bachelor's degree. When marital status of them was assessed, it is ascertained that $64,7 \%$ (33) is married (Table 1).

When the question of "what is the most efficient way in the decease of infection?" was asked to the healthcare staff participated in the study, it was determined that $43,1 \%$ (22) answered as hand washing. When the method of washing hand they prefer was asked to the participants, 68,6\% (35) prefer water and general soap (Table 2).

Table 1. Some socio-demographic features of the participants $(\mathrm{N}=51)$

\begin{tabular}{|l|c|c|}
\hline Some socio-demographic features & Number & Ratio (\%) \\
\hline Age (31.66 7.34; Min:18, Max:56) & 16 & 31.4 \\
$18-27$ & 27 & 52.9 \\
$28-37$ & 8 & 15.7 \\
38 and older & 27 & 53.0 \\
\hline Gender & 24 & 47.0 \\
Woman & & \\
Man & 9 & 17.6 \\
\hline Profession & 28 & 54.9 \\
Physician & 5 & 9.8 \\
Nurse & 9 & 17.6 \\
Medical Assistant & & \\
Auxiliary Staff & 7 & 13.7 \\
\hline Educational Status & 23 & 45.1 \\
High School & 10 & 3.9 \\
Associate Degree & 2 & 2.0 \\
Bachelor's Degree & 1 & 15.7 \\
Master Degree & 8 & \\
Doctorate Degree & & 35.3 \\
Specialist Physician & 18 & 64.7 \\
\hline Marital Status & 33 & \\
Single & & \\
Married & & \\
\hline
\end{tabular}


Table 2. Some features of participants about hand washing applications $(\mathrm{N}=51)$

\begin{tabular}{|c|c|c|}
\hline Some features about hand washing applications & Number & Ratio (\%) \\
\hline $\begin{array}{l}\text { What is the most efficient way in the decease of infection? } \\
\text { Hand washing } \\
\text { Hygiene } \\
\text { Training } \\
\text { No answer }\end{array}$ & $\begin{array}{c}22 \\
18 \\
6 \\
5\end{array}$ & $\begin{array}{l}43.1 \\
35.3 \\
11.8 \\
9.8\end{array}$ \\
\hline $\begin{array}{l}\text { Is hand washing necessary in the case of wearing gloves? } \\
\text { Yes } \\
\text { No }\end{array}$ & $\begin{array}{l}36 \\
15\end{array}$ & $\begin{array}{l}70.6 \\
29.4\end{array}$ \\
\hline $\begin{array}{l}\text { Is there any method of hand washing? } \\
\text { Yes } \\
\text { No } \\
\text { No answer }\end{array}$ & $\begin{array}{c}42 \\
7 \\
2\end{array}$ & $\begin{array}{l}82.4 \\
13.7 \\
3.9\end{array}$ \\
\hline $\begin{array}{l}\text { What is the method preferred in hand washing? } \\
\text { Only water } \\
\text { Water and general soap } \\
\text { Water and liquid soap belong to him/herself } \\
\text { Disinfectant } \\
\text { Alcohol }\end{array}$ & $\begin{array}{c}8 \\
35 \\
2 \\
3 \\
3\end{array}$ & $\begin{array}{l}15.7 \\
68.6 \\
3.9 \\
5.9 \\
5.9\end{array}$ \\
\hline $\begin{array}{l}\text { Frequency of washing hands? } \\
\text { Often } \\
\text { Occasionally } \\
\text { Before and after eating and going to toilet }\end{array}$ & $\begin{array}{c}43 \\
7 \\
1\end{array}$ & $\begin{array}{c}84.3 \\
13.7 \\
2.0\end{array}$ \\
\hline $\begin{array}{l}\text { Status of washing hands before and after the operations carried out } \\
\text { by wearing nonsterile gloves? } \\
\text { Both before and after } \\
\text { Only beforehand } \\
\text { Only after } \\
\text { No answer }\end{array}$ & $\begin{array}{c}30 \\
1 \\
18 \\
2\end{array}$ & $\begin{array}{c}58.8 \\
2.0 \\
35.3 \\
3.9\end{array}$ \\
\hline $\begin{array}{l}\text { What are the most important obstacles affecting washing hands / } \\
\text { application of hand washing suggestions? } \\
\text { Lack of stuff } \\
\text { Lack of time } \\
\text { Emergence of irritation, itch on hands } \\
\text { There is not any obstacle } \\
\text { No answer }\end{array}$ & $\begin{array}{c}12 \\
6 \\
4 \\
6 \\
23\end{array}$ & $\begin{array}{c}23.5 \\
11.8 \\
7.8 \\
11.8 \\
45.1\end{array}$ \\
\hline $\begin{array}{l}\text { The method preferred in drying hands? } \\
\text { Hand drying machine } \\
\text { Single use towels } \\
\text { A towel belong to him/herself } \\
\text { Clean piece of paper }\end{array}$ & $\begin{array}{c}13 \\
36 \\
1 \\
1\end{array}$ & $\begin{array}{l}25.5 \\
70.6 \\
2.0 \\
2.0\end{array}$ \\
\hline
\end{tabular}




\section{DISCUSSION}

Hand washing is the process of washing hands with soap and water in hospitals with the aim of preventing transmission of bacteria among patients and health staff. It is the simple, cheap and most efficient way of preventing hospital infections. However, it has been detected in the studies carried out that hand washing is not paid necessary importance despite it has a substantial place in generation of infection $(27,28)$. This research was carried out with 51 healthcare staff working in Intensive Care Clinics of a state hospital of a province in service in Bingöl State Hospital who accepted participating in the research with the purpose of determination of knowledge and attitudes on hand hygiene.

When individual features of the healthcare staff attended to the research were analyzed; it was detected that age average is $31.66 \pm 7.34$ (min:18, max: 56 ), $53.0 \%$ is woman, $64.7 \%$ is married and $54.9 \%$ is nurse. Average of age was found out as $30,31 \pm 4.53$ in the study of use of precede model directed on improvement of hand washing habits of the healthcare staff of Maraș (29). The reason for majority of the sample comprising the group is woman is thought to arise from the fact that nursing, one of the occupational groups attended to the research, is more of a profession of women and their participation in the research is in high numbers. Another reason of this might be the fact that nurses get start in the occupation just after graduation and hospital administrations' desire on creating young and dynamic teams because of high numbers of nurses in intensive care units. The reason for the fact that majority of the health staff attended to the research is married arise from physician and personnel. It is found out that greater part of nurses is single. Also, it is found out in a study carried out by Köse that $59.1 \%$ of nurses is single (11).

When the question of "what is the most efficient way in the decease of infection?" was asked to the healthcare staff participated in the study, the response of $43,1 \%$ was hand washing. The significance and necessity of hand washing of healthcare staff before and after treatment-care applications regarding patients in prevent of hospital infections has unequivocally been acknowledged. Supporting this remark, Simmelweis,
Lister and Florence Nightingale expressed that the rate of epidemics and septic deaths in hospitals can be decreased to a great extent by hand washing and suchlike hygienic applications $(30,31)$. A research conducted in Canada shows that hospital infections in intensive care units can be decreased from $30 \%$ to $10 \%$ even with only hand washing and this confirms that hand washing is the most efficient method for prevention of these infections (32).

Emergence of hospital infections can be minimized with the use of gloves and hand washing distinctly; however, use of gloves shall never substitute hand washing. it was detected that $70.6 \%$ of the participants responded "Yes" to the question of "Is hand washing necessary in the case of wearing gloves". Furthermore, when the status of healthcare staff related to the washing their hands before and after the operations require wearing nonsterile gloves is considered, it was observed that $58.8 \%$ (17) stated that hand washing is necessary before and after these operations. The rate of using gloves of healthcare staff was found out as $58.8 \%$ in the observations carried out by using Fulkerson Scale as an observation tool in the Internal Diseases service of Pamukkale University by Kuzu et.al in our country (33). It was determined in the study carried out by Keșaplı et.al in Akdeniz University emergency service in 2002 that glove was used in $38.4 \%$ of contacts and the frequency of hand washing after these touches was $27.8 \%$ (34).

When the method that the participants prefer in hand washing was asked, it was detected that $68.6 \%$ prefer water and general soap. In the study of Uzun et.al., it was established that $80.5 \%$ use water and soap as hand washing agent (35). As for Karabay et. al., it was found out that soap is more frequently used than other products among nurses (36). The results of the research that we have conducted bear resembles to the results of other researches.

When the frequencies of hand washing of healthcare staff are considered, it was seen that $84.3 \%$ replied as frequently. In the study of Esen et. al. in which they observed hand washing habits of 141 health staff, $68 \%$ of physicians, $64.9 \%$ of nurses and $63.2 \%$ of caregivers wash their hand after intervention to the patients (37). The frequency rate of hand washing in our study was found 
high among physicians and personnel.

It was designated that $23.5 \%$ of the participants cannot wash their hands because of lack of materials, $11.8 \%$ because of lack of time originating from intense work load and $7.8 \%$ because of irritation on their hands. In the study carried out by Akyll, $44 \%$ of nurses stated that the factor preventing hygienic hand washing is the number of patients is high and the number of nurses is inadequate (38). As for the study carried out by Uzun and Bölükbaș, it was specified that nurses assert at the rate of $67.6 \%$ that they cannot wash their hands frequently as they are too busy (39).

It was detected that $70.6 \%$ of healthcare staff dry their hands with hand dryer and $25.5 \%$ with single use towels after hand washing. The rightest choice in hand drying is the use of paper towels. Drying hands with paper towels is quicker than hand dryers. Drying hands takes 7-9 seconds in this way. 78.7\% of nurses notified in Akyll's study that usage of single use paper towels is the most accurate method of hand drying (38). In the study carried out by Köse, $47.7 \%$ of the group stated that they dry their hands with heated air and $45.5 \%$ with paper towels (11).

It has been observed in the state hospital where the research was carried out that sufficient hand hygiene cannot be provided and it is seen that the habit of hand hygiene could not be gained sufficiently. Findings reveal that physical conditions of healthcare personnel fall short in some occasions. Some interventions targeting all occupational groups directed on improving the attitude of hand hygiene in intensive care units are required.

Within the direction of these results, we suggest that healthcare staff shall be keep informed on the significance of hand washing and methods and materials to be used with training programs to;

-Increase the number of attitudes of hand washing of healthcare staff,

-Increase the time they spare for hand washing, -Increase their knowledge on hand washing,

-Eliminate the situations preventing their hand washing and decrease their being seen as obstacles,

-Increase the quality of the attitude of hand washing.

\section{REFERENCES}

1. Moolenaar RL, Crutcher JM, San Joaquin VH, et al.A prolonged outbreak of Pseudomonas aeruginosa in a neonatal intensive care unit: Did staff fingernails play a role in disease transmission? Infect Control Hosp Epidemiol, 2000; 21: 80-5.

2. Dokuzoğuz B., Hand washing and hand antiseptics. ANKEM Journal, 2003;17(3):154-156.

3. Boyce JM, Pittet D. Guideline for Hand Hygiene in HealthCare Settings. Recommendations of the Healthcare Infection Control Practices Advisory Committee and the HIPAC /SHEA/APIC/IDSA Hand Hygiene Task Force. Am J Infect Control, 2002; 30: l-46.

4. Bischoff WE, Reynolds TM, Sessler CN, Edmond MB, Wenzel RP. Handwashing compliance by health care workers. Arch Intern Med, 2000; 160: 1017-21.

5. Kanra G., Öncel S., Healthcare Personnel and Hand Washing Applications. Hospital Infections Journal, Bilimsel Tip Publishing House, Ankara, 1997; Volume. 1, No. 2;57-60.

6. Güner S., The effect of surgical hand washing on $\mathrm{Gr}(-)$ and $\mathrm{Gr}(+)$ bacteria on nurses' hands. İstanbul University. Institute of Medical Sciences, Master's Thesis, İstanbul, 2002.
7. Aksoy G. A study on the process of hand washing of health care personnel working in surgery. National Surgery Congress 90, Surgery Nursing Department, İstanbul, 1990.

8. Dragos AZ. Hand Washing and Disinfection. The International Symposium and Workshop on Hospital Hygiene and Hospital Infection Control. Ege University Pres, İzmir, 1996.

9. Wilson J. Keeping MRSA in Perspective. Nursing Times, 1996; Vol:92, No:19: 58-60.

10. Ener B. Role and Training of Medical Proficiency. Infection control seminar, İstanbul, 1998.

11. Köse E. Determination of the factors affecting the frequency of hand washing in urgent surgery units. İstanbul University Institute of Medical Sciences Surgical diseases nursing USA, Master's Thesis, istanbul, 1998.

12. Titiz i. Cost of hospital infections. Journal of modern hospital administration, Merajans Ltd. Şti. İstanbul, 2000; Volume:4, Number:1. 
13. Ducel G., Fabry J., Nicolle L., Prevention of Hospital-acquired Infections, a practical guide, 2nd edition, World Health Organization, 2002; WHO/ CDC/EPH2O02.12.

14. Dramalı A. Functions of nursing on preventing hospital infections, E. Ü. Journal of School of Nursing, 1987; 3:100-109.

15. Cetin ET. The Significance of hospital infections, 1st Turkish Hospital Infection Congress, Congress Book. İstanbul Medical Faculty, 7-10th of January, 1992.

16. Sarasi L., East J. Marceting Infection Control, Nursing Times, 1991; Vol: 87, No: 24.

17. Bal Ç. Infection control studies in various centers in Turkey. Infection control seminar. İstanbul, 1996.

18. Harknes GA., Dinchers J.R. Medical Surginal Nursing, Total Patient Care. Copyright. Mosby. Philadelphia, 1996.

19. Hamzaoğlu O., Kurt Ö. Epidemiology of hospital infections. Incision Surgical Sciences Journal, Bilimsel Tıp Bookstore, Ankara, 2000; Volume:3, Number:4.

20. Topçu AW., Söyletir G., Doğanay M. Infection Diseases. Nobel Bookstores, Ltd. Şti. Alemdar Ofset, İstanbul, 1996.

21. Işık AF. Legal aspect of hospital infections. Hospital infections journal, Bilimsel Tip Bookstore, Ankara, 2000; Volume:4, Number:4.

22. Yalçın An. Cost-benefit analysis of infection control programs. Hospital Infections Journal, Bilimsel Tip Bookstore, Ankara, 2000; Volume:4, Number:2.

23. Esen S., Leblebicioğlu H. and Study Group. Prevalense of Nosocomial Infections at Intensive Care Units in Turkey: A Multicentre 1-Day Point Prevalence Study. Scan J Infect Dis, 2004; 36: 144-8.

24. Kampf G., Kramer A. Epidemiologic backround of hand hygiene and evaluation of the most importanat agents for scrups and rubs. Clinical Microbiology Rewiews. 2004; Vol. 17, No. 4: 863-893.

25. Çetinoğlu E.Ç., Canbaz S., Aker S., et. al. Ondokuz Mayıs University Medical Faculty Hospital Assessment of the knowledge of nurses on the issue of hand washing. 4th National Sterilization Disinfection Congress Book, Bilimsel Tip Publishing House, Ankara, 2005;745.

26. Craven DE., Kunches LM., Lichtenberg DA., et al. Nosocomial Infection and Fatality in Medical and Surgial Intensive Care Unit Patients. Arch Inter Med, 1988; 148:1161-8.

27. Güçlü E, Tuna N, Yahyaoğlu M, Çalıca Utku A, Özcan Ö, Ceylan S, et al Efficacy of education and dissemination of alcoholbased hand antiseptics in the hospital in improving hand hygiene compliance. Flora, 2012; 17:118-25.
28. Özen Ş, Dramalı A. Comparison of knowledge and attitudes of nurses on hand washing and usage of gloves in infection control. 3rd National Nursing Congress. Sivas, 1992.

29. Maraș GB. Use of de Precede model in improvement of hand washing habits of healthcare personnel (Master's Thesis).izmir: Ege University Institute of Medical Sciences, 2007.

30. Rotter ML. Hand washing and hand disinfection. In: Mayhall CG (ed). Hospital Epidemiology and Infection Control. 3rd ed.Philadelphia: Lippincott Williams and Wilkins, 2004; 1727-46.

31. Görak G., Savașer S. Control methods (Medical asepsis) current approach on hospital infections. N: 42-48, Edi:i. Titiz, D. Şelimen, T. Yatlı. Yeni Ruket, İstanbul, 1997.

32. Conly JM., Hill S., Ross J., Lertzman J., Louite TJ. Handwashing Practices in an Intensive Care Unit: The Effects of an Educational Program and its Relationship to Infection Rates. Am J Infect Control, 1989; 17,330-9.

33. Kuzu N., Özer F., Aydemir S., et. al. Compliance with Hand Hygiene and Glove Use in a UniversityAffiliated Hospital. Infection Control and Hospital Epidemiology, 2005; 26, 3: 312-315.

34. Keșaplı M., Çete Y., Kartal M., Property of hand washing in emergency service and the factors affecting it. Turkish Clinics Medical Sciences Journal, 2004; 24 (3): 235-242.

35. Uzun G, Erden H, Mert H, Atmaca D. The importance of hand washing in hospitals particularly in surgery clinics. International surgery congress, surgical nursing department, lecture and declarations, İstanbul, 1990; 221-225.

36. Karabay O, Sencan I, Sahin I, Alpteker H, Ozcan A, Oksuz S. Compliance and efficacy of hand rubbing during in-hospital practice. Med Princ Pract., 2005; 14:313-7.

37. Esen Ş, Kumcağız H., Sünbül M., Eroğlu C., Leblebicioğlu $\mathrm{H}$., Point of view and attitude of the habit of hand washing of healthcare personnel in critical units. II. Sterilization Disinfection Hospital Infections congress, Samsun. Congress Book, 25-28 April 2001; 228.

38. Akyll R. Determination of hand washing status of the nurses working in hospitals, Atatürk University Institute of Medical Sciences, department of surgical diseases nursing, Master's Thesis, Erzurum, 2002.

39. Uzun Ö., Bölükbaș N. a descriptive study on hand washing and drying. Journal of nursing, 1997; 47(6): 14-17. 